\title{
Drama at Disney: A Thematic Analysis of Creative Worker Identity Negotiation and Identification in the Documentary Waking Sleeping Beauty
}

\author{
Angelique Nairn, Auckland University of Technology, New Zealand \\ Justin Matthews, Auckland University of Technology, New Zealand
}

\begin{abstract}
Work in creative organizations is often completed under intense working conditions. Due to the nature of the industry sector, creative workers must manage and deal with a range of factors related to their daily activities. These include multiple projects, tight deadlines and shifting schedules, to produce creative outputs that may have limited success in the marketplace. Despite the intensity of the work, the drive to create sets up conditions where creatives will self-exploit to meet work demands due to strong intrinsic motivations. This behaviour can leave creative workers susceptible to exploitation by employers because they offer a space for creative people to get resources and projects that meet these powerful intrinsic needs. To that end, creative people come to negotiate who they are within the constraints imposed by the work they do, and for this reason, we sought to thematically analyze the documentary Waking Sleeping Beauty (Hahn, 2009) to consider the intentional and unintentional construction of creative worker identity. We found that the identities of creatives could be categorized according to four themes: Creatives as passionate and/or exploited; Creatives as transformational, Creatives as subordinates, and Creatives as resistors. These themes revealed how animators negotiated their identities at a time when Disney Animation was experiencing several upheavals and suggested that identification with Disney could have both advantages and disadvantages for creative workers. The broader consideration from the themes alludes to a need to consider how to best provide for the creative worker while still capitalizing on the business needs of the creative economy.
\end{abstract}

Keywords: animation, creative identity, Disney, identification 


\section{Introduction}

Work in the creative industries is often project-based, with tight deadlines, exploitation of workers for commercial gain, and no guarantee that the final creative product will be a success in the marketplace (Bridgstock, 2008; Caves, 2000; Hesmondhalgh \& Baker, 2009). Yet creative people accept or abide by these conditions and pressures to fulfill their intrinsic motivations (Amabile \& Mueller, 2007). The impact on their identities, however, can be problematic with scholars arguing that these conditions are responsible for pushing creative people to subordinate their private and personal aspects of life to their jobs (Kreiner \& Ashforth, 2004) and in extreme circumstances, to become addicted to work (Rowlands \& Handy, 2012). The purpose of this article, then, is to explore the documentary Waking Sleeping Beauty (Hahn, 2009) for evidence of intentional and unintentional construction of worker identity, with particular attention paid to the identification process. The significance of exploring the construction of worker identity in Waking Sleeping Beauty lies in its focus on the Disney company. As one of the most successful global corporations, Disney's approach to management and creative projects could be replicated, and therefore can set standards for employees that favor certain working conditions for creative people. Furthermore, the documentary captures the working practices of creative people before a creative economy was advocated, suggesting the insights from the documentary may assist in determining how the identities of creative workers and the conditions of creative employment may have developed and perhaps even have evolved.

To explore the identity implications experienced by creative workers, we thematically analyzed the documentary Waking Sleeping Beauty, directed by former Disney animator Don Hahn and produced by former Vice President of Animation, Peter Schneider (Farber, 2009). Waking Sleeping Beauty chronicles the highs and lows experienced by the Disney animation studio from 1984 to 1994 (Hahn, 2009; Farber, 2009; Macaulay, 2010). In an interview for the film, Hahn and Schneider discuss how the documentary was an opportunity to tell their story (Macaulay, 2010). Although the tumultuous relationships of the executive management team have been well documented elsewhere (see Stewart, 2005 for an account of the "DisneyWar"), Schneider wanted the documentary to "capture amidst all the drama ... the joy that exists while you are making a creative project. I wanted to capture the extraordinary joy of that period of time as well as the personal drama" (Macaulay, 2010). Featured in the film are Michael Eisner (CEO and Chairman), Frank Wells (Chief Operating Officer), Jeffrey Katzenberg (Head of Film Division), Roy Disney (President of Disney Animation), Peter Schneider as well as numerous animators and contractors (Macaulay, 2010).

The film itself includes archival footage, interviews with those working at Disney at the time, news footage, and footage from animation films produced across the ten years of the documentary. The film, then, offers viewers a glimpse into how employees working at the company interpreted how they felt, what they believed, and how they navigated situations at a time of crisis, and later, euphoria (Hahn, 2009). In essence, the film demonstrates how individuals working for Disney were able to negotiate their own identities, and how they acquired a sense of self by acting within a social structure (Brown, 2017). That is, the employees are encouraged to engage in identity work where they construct the story of that time. It allows them to distance themselves from traits or attributes that they deem unflattering or threatening, adopt resources to assign labels to the self and finally, reflect on perceptions held by others (Beech, et al., 2012). Therefore, we were able to analyze a myriad of perspectives on the situations in Disney Animation to consider the identities forged and the identifications that were lost or maintained. 


\section{Literature Review}

\section{Identity, Identification, and Disidentification}

Generally speaking, identities are the self-meanings used to sustain individuality (Parekh, 2009; Stets \& Burke, 2000). Identities include the "core beliefs, assumptions, values, attitudes, preferences, decisional premises, gestures, habits and rules" (Scott, et al., 1998, p. 303) that people adopt and it is these distinctive traits that help individuals establish a sense of uniqueness (Sluss \& Ashforth, 2007). Stereotypically, creative people have been considered intelligent, immature, aware and receptive, independent, autonomous, flexible, introverted, self-confident, unconventional, and asocial (Bain, 2005; Beir, 1995). In other words, their sense of 'uniqueness' hinges on their intrinsic drive and need to be free. Accordingly, it also requires a degree of identity work to "... establish an identity in their estimation and in the eyes of others" (Beech, et al., 2012, p. 40). People develop their identities by evaluating the responses and perceptions of others (Stets \& Burke, 2000). For example, Brooks and Daniluk (1998) found that visual artists look to their peers for recognition, acceptance, and support and when these were experienced, the artists felt more comfortable and satisfied with their creative work. Of course, some exceptions find fulfillment in their own understandings, such as a writer in Day's (2002, p. 133) research who remarked: "I don't need other people's validation. I know what I am." However, more often than not, identity negotiation comes from individuals surrounding themselves with like-minded others who support and augment one another's identities (Swann, et al., 2000).

In developing their identities, people can look to identify with organizations to experience feelings of belonging and esteem (Hogg, et al., 2017; Karanika-Murray, et al., 2015; Miscenko \& Day, 2016). Identification occurs when individuals define their self-concepts in-line with their memberships of particular social categories, such as employing organizations. Accordingly, when people perceive commonalities with a social category, they will internalize aspects of the organization into their self-definition (Ashforth \& Mael, 1989; Brown, 2017; Dutton, et al., 1994; Karanika-Murray, et al., 2015; Miscenko \& Day, 2016; Scott, et al., 1998), such as ethical and value-laden premises (Tompkins \& Cheney, 1985; Lee, et al., 2015). By choosing to identify with certain social categories and organizations, individuals develop ingroup affiliations that naturally construct other categories and organizations as out-groups (Hogg, et al., 2017; Tajfel, 1982). These in-group/out-group distinctions allow individuals to establish positive distinctiveness and are not problematic until in-group members engage in practices of favoritism and bias that elevate the status of their own group above that of the outgroup (Stets \& Burke, 2000; Tajfel, 1982). For example, when creative people perceive that only like-minded others understand their work, they subordinate employers and clients. Such in-group bias perhaps accounts for some of the tension that exists between Creatives and Suits in the creative workplace (Hackley \& Kover, 2007).

By identifying with an organization, individuals adapt their behavior to the needs of the organization, which can guide individuals' thinking and behavior (Scott, et al., 1998) and predispose individuals to conforming and committing to organizational expectations (Ashforth \& Mael, 1989; Lee, et al., 2015). For example, in the case of creative people, identification creates direction that wards off procrastination (Bilton, 2007) and creates expectations that can be challenged to generate even more creativity (Adarves-Yorno, et al., 2007). The influence of the organization over the creative person's identity can lead to greater productivity and on a personal level help creative people establish their signature style (Elsbach, 2009). Identification can be mutually beneficial for both parties: the creative person is afforded guidelines and resources to pursue their creative impulses, while the organization benefits financially from the 
creative work that is produced. However, identification with an organization may not always be a positive experience (Ashforth, 2016). In some cases, people identifying with an organization can come to feel "shame, disgrace and embarrassment" (Dutton, et al., 1994, p. 242), which can eventually turn to disidentification.

Disidentification is a cognitive state entered by individuals who, having compared and contrasted the social situation, become disaffected from a previously valued in-group and begin to perceive it as an out-group (Ashforth \& Mael, 1989; Ashforth, et al., 2008; Ashforth, 2016; Parekh, 2009). Those who disidentify will overlook any perceived similarities they may previously have had with the organization and will instead focus on the negative defining characteristics of the organization, such as conflicting values, visions, and cultures. For example, when creative organizations privilege profit maximization over creative and artistic pursuits, Creatives may become frustrated and dissatisfied to the point that they leave the organization or make their displeasure known (Powell, 2007). People might engage in sarcasm, cynicism, striking and sabotaging others (Clegg, et al., 2008), and creative people, in particular, will opt to frame creative products as separate from the self or blame others for undesirable decisions or outcomes (Elsbach \& Dukerich, 2016). As Hackley and Kover (2007, p. 75) argue, Creatives will "create a semi-permanent state of marginalisation", if necessary, to express "their resentment at the internal structures... and the overbearing influence of management ideologies." For creative people then, maintaining their standards of creativity, autonomy and professional integrity (Elsbach \& Flynn, 2013) can prompt defining the self "... as not having the same attributes or principles that he or she believes define the organization" (Kreiner \& Ashforth, 2004, p. 3).

\section{Conditions that Impact Creative Work}

Work on creative projects can be characterized as being driven by a Creative's desire for fulfilling intrinsic motivations (Amabile \& Mueller, 2007; Reid, et al., 2016). That is, rather than working to make money, gain a promotion, or achieve a level of stability (Bridgestock, 2005), a creative person will engage in creative projects to pursue a personal creative vision (Amabile \& Mueller, 2007; Reid, et al. 2016). As Beir (1995, p. 501 emphasis in the original) attests, creative people "...work for three things: first, the fun of being part of the creation itself. Second, admiration, especially from their peers. Third, the excitement and glory of taking part in a successful creation," which can mean they will sacrifice private and personal aspects of their lives to ensure focus is centered on creative work. For some creative people, this intrinsic drive means postponing personal developments such as starting a family (Taylor \& Littleton, 2012), while for others, it can mean embracing the stereotypical, romantic image of the artist who staves off real connections. For instance, Eikof and Haunschild (2006) found that creative people would not invest in material possessions and established loose ties with others, so that they could move around to follow their creative passions and place their attention on their creative work. In other words, creative people prefer to work autonomously and need the freedom to take risks and pursue new ideas (Moultrie \& Young, 2009), even if that means subordinating the private self in favor of the professional self.

The need to create - sometimes referred to as a calling - may produce creative work that is a manifestation of Creatives' core values and ways of being (Andriopoulos \& Gotsi, 2001). For example, a visual artist explained that she had a "deep 'passion' for her work and said that she would feel 'slightly ill' if she was not performing" (Brooks \& Daniluk, 1998, p. 254), while writers felt that the stories in their books were a means of grappling with their own life problems (Day, 2002). Creative people become emotionally and personally tied to their work and their passion, which can produce over-identification to the point that the creative vision 
becomes an obsession or addiction (Gotsi, et al., 2010; Rowlands \& Handy, 2012). Having salient creative identities and rejecting a work-life balance in favor of engaging in creative work can produce counter-productive behavior. For example, as one Creative expresses, ". . . at the same time it [too much emphasis on artistic expression] can be very stressful and it can lead to burn out. It can lead to very emotional, angry people at times, and I'm sure that has a negative effect on creativity" (Gotsi, et al., 2010, p. 788). In essence, creative people can impede the success of their creative vision and work because they sacrifice other roles and relational identities that would produce alternative frames of reference (Parkeh, 2009) and are predisposed to over-identify with their creative role to the point that over-familiarization and over-specialization occur, stifling creativity (Bilton, 2007).

Of course, being driven by an intrinsic need to create can cause tensions in creative organizations. Unlike creative people, administrators and managers or Suits tend to favor extrinsic motivations, which sees a clashing of ideologies that can manifest in a hostile work environment (Beir, 1995; Bilton, 2007). At the very least, Creatives and Suits find themselves separated by "mutual suspicion, defensiveness, and culturally-embedded assumptions and values" (Bilton, 2007, p. 1), which perhaps accounts for why creative people believe noncreatives do not truly understand and appreciate their creative products and look to peer recognition for validation (Powell, 2007). The tension between Suits and Creatives is exacerbated when creative people are expected to develop high-quality products under intense working constraints (Gil \& Spiller, 2007). In essence, to keep costs down, Suits will expect creative people to work long hours (Hesmondhalgh \& Baker, 2009) to tight deadlines and budgets. However, such circumstances can limit creativity in favor of meeting market demand and the creative organization's pragmatic needs (Gil \& Spiller, 2007). It falls to the creative people, then, to navigate the tension between being creative and making money, as competition for jobs in creative organizations is intense (Hesmondhalgh \& Baker, 2009) and Creatives may be replaced if they do not conform to organizational needs.

Adding to the tensions that both Creatives and Suits experience in undertaking creative work is the uncertain demand that characterizes creative products (Caves, 2000). Uncertain demand refers to how creative products are considered experience goods, meaning how audiences respond to creative products, in this case animated movies, is entirely subjective (Caves, 2000). Creative projects require a lot of upfront investment and are not guaranteed success, which perhaps explains why organizations place undue constraints on creative workers and prefer to produce standardized products (Huws, 2010; Peterson \& Anand, 2004). These working conditions, coupled with the innate need to define the self, are central concerns within creative workplaces. Our exploration of identity construction and processes of identification in Waking Sleeping Beauty can reveal insights into how creative people navigate the creative workplace and their roles within it.

\section{Method}

Thematic Analysis (TA) is a methodology and type of analysis within the umbrella of qualitative analysis. TA provides a process for "identifying, analyzing, and reporting (themes) within data" (Braun \& Clarke, 2006, p.79). The method allows a researcher a process to identify common topics or themes present in a data set or media artefact (such as a television show or film). These themes are generated by coding large quantities of data into small but meaningful units that form the basis for identifying patterns. Insight is gathered, because the method requires unpacking the data in detail, rather than relying on simple descriptions. According to 
Ibrahim (2012, p. 40) thematic analysis is considered an appropriate method for determining "the relationships between concepts" and whether they are "replicated" within the data.

Thematic analysis was conducted by watching the documentary multiple times, to identify patterns, trends, keywords, and ideas before establishing codes. These codes, or basic segments of the data, were perceived to be "interesting features" or key understandings (Braun \& Clarke, 2006 , p. 87) that were initially quite broad, but through rigorous comparison and assessing the compatibility of codes (Boyatzis, 1998; Braun \& Clarke, 2006) were able to be reduced to those themes discussed in the data analysis to follow.

The documentary revealed four key themes: Creatives as passionate and/or exploited; Creatives as transformational; Creatives as subordinate, and Creatives as resistors. Creatives as passionate and /or exploited was comprised of sub-themes such as fulfilling the creative vision, working long hours, sacrificing for the job, having fun at work, rewards, and motivations. The culmination of these subthemes led us to determine that creative people were passionate about the company and the work being done and wanted to retain their place at Disney despite unfavorable and exploitative working conditions. The theme Creatives as transformational included sub-themes such as aura, inspiration, equality, servant leadership, creativity as key, personal change, and investment. Often these sub-themes accompanied narratives about particular leaders, and in most instances, led followers to alter their behavior to emulate and support the leaders' visions. Creatives as Subordinate incorporated sub-themes such as money v. creativity, transactions, reprimand and punishment, emotional upheaval, and dissatisfaction. Finally, our fourth theme, Creatives as Resistors, was made up of sub-themes such as rebellious activity, unflattering depictions of peers, and conflict.

\section{Analysis and Discussion}

Work in creative organizations can impact how individuals negotiate their creative identities (Beech, et al., 2012). Although driven by intrinsic motivations, the confines of an organization can reorient creatives to fulfilling commercial goals, which can see workers conforming to the needs of an organization, sometimes at the expense of creativity (Eikof \& Haunschild, 2007). For those working in the Disney Animation Studio from 1984 to1994, identification with the company would see them producing award-winning films, but in fraught and sometimes emotionally and physically jarring circumstances.

\section{Theme 1: Creatives as Passionate and/or Exploited}

Throughout the documentary, it became clear that creative people were willing to work "around the clock" (Hahn, 2009, 00:44:21-22) because they were "living the dream" (Hahn, 2009, 01:05:03-01:05:05). Such evidence of their passion and commitment to the work was made clear when Hahn referred to how, as part of the animation marathon of making one film a year, the animators ended up spending "more time with each other than we did with our families" (Hahn, 2009, 00:55:13-16). As the success of animated movies grew, the animators were pushing themselves, as Hahn put it "trying to top ourselves" (Hahn, 2009, 01:04:32-33), because the rewards increased, and credit ensued. The drive to do better and make a name for themselves both as animators and individuals suggests that the animators held salient creative identities, which were elevated in the hierarchy of individual identities. Continually privileging one identity over another can lead to over-identification and a degree of self-exploitation (Gotsi, et al., 2010; Rowlands \& Handy, 2012). These aspects demonstrate that the animators identified with Disney and the movie projects to the point that productivity increased, and they were willing to invest more to see the films come to fruition (Powell, 2007). 
It was clear in Waking Sleeping Beauty that the animators were willing to push themselves to get work done to the point that "everybody was spread too thin" (Hahn, 2009, 01:05:53-55). In fact, in a meeting held by Katzenberg with the animators, they discussed how they could not have a family because of the pressure they were under to complete the films and that some animators had developed carpal tunnel syndrome in response to the pressure to make many animated films in short timeframes. Animator Glen Keane describes how his hands would shake making it difficult to hold a coffee cup because he had been "animating the whole night before" (Hahn, 2009, 01:04:04-06). While making the movie Rescuers Down Under (USA, 1990), animators took to sleeping on pellets on the floor because the new computer system had to be regularly monitored and that meant there was no time to go home if the project was to be finished on time and to a reasonable quality. Essentially, the animators were working irregular hours trying to get everything completed, and in so doing demonstrated a commitment to the project. Furthermore, the process was being overseen by Schneider who always wanted to know if the new computer system they were trialing was working, and that added to the pressure felt by the animation team. As expressed by Hahn in the documentary "the deadlines and quotas never stopped" (Hahn, 2009, 00:44:27-29), and "the work was intense, the hours long" (Hahn, 2009, 00:54:50-55). Creative people will work when they are inspired and struggle with maintaining a healthy balance between work and home (Bain, 2005; Rowlands $\&$ Handy, 2012). However, the suggestion from the documentary is that the workload, not the inspiration, was requiring the creative people to sacrifice their personal needs in favor of professional requirements. Although the Creatives may have been passionate and committed, it is clear that a degree of exploitation is observable.

The animators were not just engaged in their own exploitation but were also overtly and covertly exploited by Disney management. In Waking Sleeping Beauty, animators were forced to abide by the dictates of the leadership for fear of losing their jobs. For example, both Jeffrey Katzenberg and Peter Schneider fired people who were "belligerent" (Hahn, 2009, 00:26:2223 ), and Katzenberg regularly made decisions that pushed the animators to work harder and faster. To make Beauty and the Beast (USA, 1991) the animators had to not only start again when Katzenberg scraped the first six months of work, they were also tasked with developing a film with a budget and a schedule that Hahn describes as "cut way, way back" (Hahn, 2009, 00:45:54-56). The exploitation of the animators appeared to be financially motivated, because as Katzenberg and Eisner varyingly attest "more titles" would mean that Disney could do "better financially" (Hahn, 2009, 00:43:01-04). The fact that animation "cost a fortune to create" (Hahn, 2009, 00:27:17-18), with any one film needing "half a million frames" (Hahn, $2009,00: 27: 29-36)$ and costing upwards of 10 million USD to make, it was unsurprising that money-making was a key agenda of the managers at Disney.

Disney is first and foremost a business, and those running the organization typified the Suit mentality of needing a return on investment and extrinsic rewards to ensure the continuation of the organization (Beir, 1995; Bilton, 2007). However, the toll of needing to return a profit was felt primarily by the animators who regularly had "cold dinners" and forfeited "nights away from family" (Hahn, 2009, 01:05:01-03). Yet despite the fraught work conditions, creative people continued to push themselves to make the films, which can perhaps be explained by the fact that when individuals identify with an organization, they will submit to that organization's juristic power and organizational control (Tompkins \& Cheney, 1985).

The analysis shows that the animators were passionate about their work. Their passion and investment in the organization were eventually rewarded with the company winning awards, having box office success, and investing in new creative partnerships and resources. In these 
ways, the creative people were able to experience the "fun," "admiration" and "glory" (Beir, 1995, p. 501) fundamental to creative drive and fulfilling a creative vision. According to Lee (1971), worker identification and commitment to an organization are maintained as rewards and status increase. Although not typical of creative people who prefer intrinsic motivations (Amabile \& Mueller, 2007; Reid et al., 2016), these extrinsic motivations, such as credit and a brand-new building, did keep creative people focused and tied to the animation projects. Once commitment with an organization is established and individuals strongly identify with the organization, this dedication will remain "relatively stable and enduring" (Gautam et al, 2004, p. 305) despite personal costs.

\section{Theme 2: Creatives as Transformers}

The second theme identified in Waking Sleeping Beauty is Creatives as transformers. In the documentary, there were several instances where creative leaders were able to empower their colleagues and give meaning to the creative work, which stimulated the creative process and transformed the creative projects and environment. For example, when Peter Schneider was hired to run the animation department, he believed his first objective was to "change the culture before it changed me" (Hahn, 2009, 00:22:57-58) because it was clear that the company had lost its identity and needed to be altered to "make great films" again (Hahn, 2009, 00:24:0406). He revolutionized the creative process by taking everything apart, bringing in motivational speakers, and challenging animators to defend their creative ideas. Successful leaders often embody the prototypical characteristics that define the organization and the work they do (van Knippenberg \& van Kleef, 2016) and in this instance, Schneider's focus on the creativity rather than commercial benefits likely endeared the creative people to him and assisted in forging a collective identity that bound the animators together. In many ways, Schneider embodied the traits of transformational leadership by reinforcing the company vision of making great films and thus moving stereotypically driven creative people to work together for the common good (Andriopoulos \& Gotsi, 2001). The transformational approach can be seen to energize an organization (Clapham, 2000), and in this case, many animators felt like they were "on a freight train leaving the station at light-speed" (Hahn, 2009, 00:23:27-30), they had to get on board to reap the benefits of the change.

Schneider was not the only transformational leader identified in Waking Sleeping Beauty. Howard Ashman, a composer with a background in musical theatre, was hired to help inject creativity into the musical numbers of animation films. He was described as a "real genius at work" (Hahn, 2009, 00:38:27-32), and he had "an amazing influence on everybody" (Hahn, 2009, 00:51:29-00:51-31). His influence is notable in the making of The Little Mermaid (USA, 1989), as his development of the song "Part of your world" inspired animator Glen Keane to feel compelled to draw Ariel: "I have to do Ariel, I can feel it in my heart" (Hahn, 2009, 00:40:55-59). Therefore, Ashman was able to transform projects by relying on his expertise and relatability. According to Mumford, et al. (2002), leaders with proven expertise can guide and influence others because their superior knowledge and proven ability can, as Lunenburg (2012, p. 6) points out, "...lead to enthusiastic and unquestioning trust, compliance, loyalty, and commitment from subordinates." In other words, the animators trusted Ashman because of his theatre background and understanding of the creative process and deferred to him since he was likable and respected. This trust and respect, coupled with participative safety (West, 1990; Pirola-Merlo \& Mann, 2004) is perhaps what prompted Keane to feel comfortable in becoming personally and emotionally tied to the work (Bain, 2005) and especially to the creation of Ariel. 
Not all the transformational leaders remained transformational throughout the creative process nor were they always successful in creating unity and conformity within the teams. The directors of Beauty and the Beast found Ashman to be intimidating and, at times, difficult to work with because he preferred his ideas over others. In one such incident, Ashman yelled at the directors for rejecting his idea to have a "little beast boy" (Hahn, 2009, 00:49:18-19) in the prologue of the movie. Elsbach and Flynn (2013) found that creative people who offer creative ideas do so to affirm their own identities. When those creative ideas are not validated by their peers, the lack of support might produce uncertainty and defensive behaviors in people looking to preserve their self-concepts. Ashman's transformational approach, then, was not always appreciated or conducive to collegiality, suggesting that leadership is context-dependent, and the creative process requires give and take (Mainemelis, et al., 2015). Similarly, another transformational leader, Don Bluth was according to Hahn, seen by some of the animators as "charismatic" (Hahn, 2009, 00:06:20-21) and the "messiah of animation," while others viewed Bluth as "just another Walt wannabe" (00:06:27-31). Again, this example is evidence that some leaders and some leadership styles can be polarizing as much as they can be transformative.

Research on the creative industries has found that the preferred leadership style for managing creative people is transformational leadership because it encourages creativity and innovation (Bass, 1990; Pieterse, van Knippenberg, Schippers \& Stam, 2010). An effective transformational leader will motivate others, ensure individuals are concerned with the common goals of the organization over their own interests, and will role model the ideal behaviors expected of those they are working alongside (Pieterse, et al., 2010). Should this approach empower employees, then creativity will be high. Both Schneider and Ashman typified transformational leadership by enforcing the vision of the company, that "animation is the heart" (Hahn, 2009, 00:01:42-44) of Disney, and bringing people together through a common bond of making great films. They shared common ground with the animators because they advocated for creativity, which is in line with Creatives' attitudes and behaviors (Amabile \& Mueller, 2007; Reid, et al., 2016), and is perhaps the reason why they were well regarded and two of the most influential leaders identified in the documentary.

Although it is clear that the animators identified with the Disney corporation, they could be said to identify with these key transformational figures as well. Communicating and interacting with like-minded others, such as Schneider and Ashman, could be why individuals opted to identify with the organization. These peers embody the prototypical characteristics that animators appreciated and respected (Lunenburg, 2012), such as creative skills and expertise, which may account for why they were so influential in the creative process.

\section{Theme 3: Creatives as Subordinates}

The third theme identified in the documentary was labeled "Creatives as subordinate" and captured the clear hierarchical decision-making process that takes place in an organization such as Disney Studios. For example, when making the film The Black Cauldron, Katzenberg determined that the movie was too dark and unlikely to be well-received in the creative marketplace. As the head of the film division and boss of the animators, Katzenberg demanded that the film was brought to an edit bay where he was "gonna show you how you edit an animated movie," despite being advised by the creative workers that "you can't just edit an animated movie" (Hahn, 2009, 00:16:11-28). In another example, Katzenberg informed the animators that he was "interested in the Bank of America Awards," which was the "worst thing to tell a room full of artists" (Hahn, 2009, 00:21:24-31) because the latter were motivated by intrinsic desires and felt their motivations were no longer taking precedence. Finally, the subordination of the Creatives was evident in their relocation to a "gutted wretch of a building" 
(Hahn, 2009, 00:19:05-07). The physical relocation of the animators typifies the in-group/outgroup distinction because removing them from the Disney lot reinforced that the animators were the distinctive and unfavorable other. Katzenberg's decision to hold 6 am meetings on weekdays and 8 am meetings on Sundays was further evidence of the animators' subordination. As Roy Disney laments, it was "such a total sign of disrespect for a lot of talented people working their asses off for you" (Hahn, 2009, 00:20:53-58). According to Rogers, Corley, and Ashforth (2017), showing workers respect and responding to their needs can enhance creativity and increase the likelihood of them identifying with their leader. In this case, however, Katzenberg did the opposite, which was demoralizing and cemented the sentiment that creativity was less important to the Disney studio at the time.

According to Caves (2000), market-orientation and commercial drive are often preferred over creativity, which inevitably constructs creative people as part of a transaction, where their inputs are dictated according to managerial requirements. The push to treat Creatives as part of a transaction is typical of those embodying the prototypical characteristics of Suits (Thompson, et al., 2007). Transactional leadership entails clarifying project expectations, the close monitoring of employee behaviors, and correcting situations that arise and prove problematic (Bass, 1990; et al., 2010). Such a leadership style inevitably advances the predilections of the leader and perhaps explains why Katzenberg's approaches placed importance on commercial imperatives as opposed to creativity and innovation. Furthermore, his leadership style could impact on how valued the employees felt, with Wrzesniewski, Dutton, and Debebe (2003, p. 127) arguing that a "close coupling between the way others make employees feel about the value of their work and how they feel valued as individuals" happens through engaging in organizational life.

For Suits, creativity is seen as one of many inputs in the production process (Thompson et al., 2007), which perhaps explains why Eisner wanted to "put a box around all of this creativity" (Hahn, 2009, 00:34:06-10) and Katzenberg felt cutting a musical number from The Little Mermaid based on early audience responses, were appropriate and desired courses of action. Whether they intended to or not, both Eisner and Katzenberg reaffirmed the in-group/out-group or Suits versus Creatives distinctions stereotypical of the creative industries. By engaging in in-group favoritism they subordinated the out-group (Stets \& Burke, 2000; Tajfel, 1982), which perhaps accounts for the reason why the creative people resented managerial intervention in their work or came to perceive that they were the "step-child" (Hahn, 2009, 00:31:42-43) in the Disney company.

From the analysis, we determined that the Disney corporation held firm to a centralized management structure that naturally subordinated the needs of the creative people. That is, a commercial agenda overlaid all creative activity, which reaffirmed distinctions between the Suits and Creatives. It is not surprising that concerns over the company's finances were given precedence, after all, Disney is a business and without a steady profit, the ability to reinvest in new animation stories would be difficult. What was unexpected, however, was that generally speaking the animators accepted the commercial goals of the organization. According to Eikhof and Haunschild (2007), when creative people are externally rewarded with, for example, a brand-new building or received higher salaries and bonuses like they were at Disney, the intrinsic motivations can be supplemented. Additionally, Elsbach and Flynn (2013) found that creative people are conscious of the pragmatic needs of an organization and can switch between being creative and being business-focused as and when required. Therefore, the subordination of the creative people was not an entirely unwelcome or negative occurrence, but rather an occasional necessity to ensure the organization's survival. 
Interestingly, the move to a creative industries agenda has seen the desires of creative people elevated above those of management (Davis \& Scase, 2000). In their research, Davis and Scase (2000, p. 87) cite the experience of a manager to emphasize this shift: "[Y]ou have to understand that I have a kind of stable of thoroughbreds here and if I treated them like junior accountants, they'd all tell me to piss off..." Yet it is clear in Waking Sleeping Beauty that the animators were not as highly prized and instead, chose to conform to managerial requirements to be rewarded and to alleviate feelings of fear. They often abided by Katzenberg's requests to avoid "negative undesirable consequences... if they do not comply" (Raven, 1992, p. 2). Therefore, Katzenberg's transactional leadership approach, which emphasized the power and wisdom of the leader (Jung, et al., 2009), inevitably impacted on the Creatives' motivations and subordinated them in the Disney hierarchy.

\section{Theme 4: Creatives as Resistors}

The final and smaller of the four themes, Creatives as resistors, demonstrated that although Creatives might have been subordinate, that did not stop them rebelling in times of inequity and frustration. For example, when the animators were told in a memo by Roy Disney that they were to be relocated to a derelict building to make way for the live-action stars, the "emotionally under my desk" (Hahn, 2009, 00:19:19-20) animators refused to do any work and instead, re-enacted the entire Apocalypse Now film. In another instance, the animators were again informed in a memo that the title of their film Basil of Baker Street would be renamed Basil the Great Mouse Detective (USA, 1986) as per the requests of both Schneider and the marketing department. To ensure their displeasure was known, the animators wrote and circulated a fake memo that undermined Schneider's integrity, slashed Schneider's tyres and drew unflattering caricatures of him. Aside from establishing in-groups and out-groups, where management and the marketing department were considered the unfavorable other, these examples reinforce the stereotype that creative people are disinclined to support the corporate culture (Beir, 1995; Hackley \& Kover, 2007; Torr, 2008) when they sense a loss of independence and freedom (Hardy \& Phillips, 2004).

The analysis of the documentary revealed that although the animators would generally abide by the managers' dictates, they did not always feel the sense of belonging and esteem that comes with identification. Identification comes from having a commonality of beliefs: a person associates with an organization that validates their self-concept and possesses characteristics that are deemed favorable and enhancing (Ashforth \& Mael, 1989; Tajfel, 1982). At times in the documentary, it was clear that the attitudes and beliefs of the animators and those of the people governing them were not congruent, which could have prompted some self-questioning and unease. The few instances of rebellion can perhaps be explained by Peretti and O'Connor (1989) who argue that when a person's sense of self is strong and held with conviction, they will reject and defend against any external attributions that threaten the individual's selfconcept.

Resistance occurs when individuals perceive personal injustices that have taken place and is seen as necessary to maintain professional integrity (Hackley \& Kover, 2007). As Elsbach and Flynn (2013) found, creative people prefer their own standards and want to have control over their projects, so the decisions of Roy Disney and Schneider to act on behalf of the animators could have been construed as a threat to the animators' self-concepts and professional understandings. In such circumstances, it is not uncommon for people to resist by striking, engaging in-jokes and sarcasm, sabotaging others, and acting in other insubordinate ways (Clegg, et al., 2008), particularly if these same individuals are grappling with disidentification. Kreiner and Ashforth (2007) have identified that when individuals oppose elements of an 
organization, in this case, organizational dictates, the negative attitudes, and feelings towards the organization will see workers become cynical and alienate themselves to maintain feelings of self-esteem and self-worth. Therefore, the Creatives of Disney Animation did not always trust or respect the actions of management if it was seen as a personal affront to their creative identities.

\section{Conclusion}

Structures of power can push people to act in ways that favor an organization at great personal expense (Huws, 2007). For example, throughout the documentary creative people were hired and fired according to the commercial needs of the business, they were pushed to work to excess to meet management goals of producing multiple projects within tight timelines, and they were instructed on what they could do and where they could work, including in a derelict building. Many of the animators remained with the company despite their despondency and frustrations. By identifying with an organization, individuals adapt their behavior to the needs of the organization, which can guide individuals' thinking and behavior (Scott, et al., 1998) and predispose individuals to conforming and committing to organizational expectations (Ashforth \& Mael, 1989; Lee, et al., 2015). Identification, then, leads to individuals orientating their behavior to meet organizational demands (Tompkins \& Cheney, 1985), even if that entails a degree of exploitation, provided these individuals are in some way rewarded (Tompkins \& Cheney, 1987).

Being part of a success story, despite having reservations and concerns about the company, may explain why the animators stayed with Disney, even though they experienced some less favorable working conditions. When an organization is perceived favorably by others, it can increase the likelihood of identification happening because individuals want to be affiliated with the organization to experience self-enhancement and self-esteem (Dutton, et al., 1994). It may even account for why the animators ultimately over-identified with the work to the point they were willing to make sacrifices to ensure they experienced personal satisfaction and the organization had creative and financial success. When creative people over-identify with their work they "can become completely consumed by work and thereby lose a sense of individual identity" (Kreiner \& Ashforth, 2004, p. 2). Other markers of identity, such as family and friends, are lost or subordinated in favor of the psychological rewards that come from manifesting their creative visions. In other words, creative people will self-exploit and in extreme situations, become prima donnas (Gotsi, et al., 2010) or addicted to work (Rowlands \& Handy, 2012), to experience creative freedom (Cohen, 2012) and the social validation of working in prestigious industries (Bridgstock, 2008; Caves, 2000; Cohen, 2012), such as Disney animation.

A lot of the stories in Waking Sleeping Beauty are accounts of interactions with others. Ashman helped Keane understand his creative potential, Katzenberg challenged creative people to understand the pragmatic needs of a business, and Schneider inspired the workers to find common ground and bond with one another. These all contributed to the ways creative people appeared to see themselves, stimulating the development of our four themes, and pointing to how identity development and identification does not happen in a vacuum. However, the insights from the documentary suggest that not much has changed since the 1980s around the development of creative identities and the working conditions encountered by creative people. Compared with recent scholarship, the suggestion is that the animators of the past and the creative workers of today, are expected to flourish under tight schedules, conflicting creative and commercial commitments, and stringent management ill-equipped to understand the needs 
of workers in the creative economy. Therefore, our research suggests the need for more consideration to be placed on how best to provide for creative workers by management, policymakers, and scholars looking to capitalize on the creative economy.

Admittedly, there are a couple of limitations to this article. The first is that the analysis is of a documentary. The focus on a singular media artefact means that themes identified and explored within this study are limited to this singular lens and particularly the constructed views of Hahn as the documentary maker. Secondly, this documentary was made twenty years prior. Accordingly, stories will have changed, emotions will have been reinterpreted, and identity negotiation will have taken effect. The documentary, then, is a snapshot in time, however, themes from our data analysis centering on creative identity and identification continue to have relevancy, as many of the working conditions evident in the documentary continue to exist in the creative industries today. To offset these limitations, interviews with current animators working at Disney would permit an evaluation of how much has changed in terms of working conditions, and how animators describe their creative identities in a contemporary context. 


\section{References}

Adarves-Yorno, I., Postmes, T., \& Haslam, S. A. (2007). Creative innovation or crazy irrelevance? The contribution of groups norms and social identity to creative behavior. Journal of Experimental Social Psychology, 43(3), 410-416. https://doi.org/10.1016/j.jesp.2006.02.013

Amabile, T. M. \& Mueller, J. S. (2007). Studying creativity, its processes, and its antecedents: An exploration of the componential theory of creativity. In J. Zhou \& C. Shalley (Eds.), Handbook of organizational creativity, (pp. 31-62). Mahwah, NJ: Erlbaum.

Andriopoulos, C., \& Gotsi, M. (2001). 'Living' the corporate identity: Case studies from the creative industry. Corporate Reputation Review, 4(2), 144-154.

https://doi.org/10.1057/palgrave.crr.1540139

Ashforth, B. E. (2016). Distinguished scholar invited essay: Exploring identity and identification in organizations: Time for some course corrections. Journal of Leadership \& Organizational Studies, 23(4), 361-373. https://doi.org/10.1177/15490151816.667897.

Ashforth, B. E., Harrison, S. H., \& Corley, K .G. (2008). Identification in organizations: An examination of four fundamental questions. Journal of Management, 34(3), 325-374. https://doi.org/10.1177/0149206308316059.

Ashforth, B. E., \& Mael, F. (1989). Social identity theory and the organization. The Academy of Management Review, 14(1), 20-39. Retrieved from https://doi.org/10.2307/258189

Bain, A. L. (2005). Constructing an artistic identity. Work, Employment and Society, 19(1), 25-46. https://doi.org/10.1177/0950017005051280.

Bass, B. M. (1999). From transactional to transformational leadership: Learning to share the vision. Organizational Dynamics, 18(3), 19-31. doi: 10.1016/0090-2616(90)90061-S.

Beech, N., Gilmore, C., Cochrane, E., \& Greig, G. (2012). Identity work as a response to tensions: A re-narration in opera rehearsals. Scandinavian Journal of Management, 28, 39-47. https://doi.org/10.1016/j.scaman.2011.12.005

Beir, J. R. (1995). Managing creatives: Our creative workers will excel if we let them. Vital Speeches of the Day, 61(6), 501-503.

Bilton, C. (2007). Management and creativity: from creative industries to creative management. Malden, MA: Blackwell, UK: Open University Press.

Boyatzis, R. E. (1998). Transforming qualitative information: Thematic analysis and code development. Thousand Oaks, CA: Sage.

Braun, V. \& Clarke, V. (2006). Using thematic analysis in psychology. Qualitative Research in Psychology, 3(2), 77-101. https://doi.org/10.1191/1478088706qp063oa

Bridgstock, R. S. (2008). 'Follow your bliss' or 'show me the money'? Career orientations, career management competence and career success in Australian creative workers. Electronic paper. Australian Policy Online. Available at http://apo.org.au/node/14938

Brooks, G. S. \& Daniluk, J. C. (1998). Creative labors: The lives and careers of women artists. The Career Development Quarterly, 46, 216-261. https://doi.org/10.1002/j.2161-0045.1998.tb00699.x 
Brown, A. D. (2017). Identity work and organizational identification. International Journal of Management Reviews, 19(3), 296-317. https://doi.org/10.1111/ijmr.12152.

Caves, R. E. (2000). Creative industries: Contracts between art and commerce. Cambridge, MA: Harvard University Press.

Clapham, M. M. (2000). Employee creativity: The role leadership. Academy of Management Perspectives, 14(3), 138-139. https://doi.org/10.5465/ame.2000.4474568

Cohen, N. S. (2012). Cultural work as a site of struggle: Freelancers and exploitation. Triple C, Cognition, Communication, Co-operation, 10(2), 141-155. https://doi.org/10.31269/triplec.v10i2.384

Clegg, S., Kornberger, M., \& Pitsis, T. (2008) Managing \& organizations (2nd ed.). Los Angeles, CA: Sage

Davis, H., \& Scase, R. (2000). Managing creativity: The dynamics of work and organization. Buckingham, UK: Open University Press.

Day, S. X. (2002). "Make it uglier. Make it hurt. Make it real": Narrative construction of the creative writer's identity. Creativity Research Journal, 14(1), 127-136. https://doi.org/10.1207/S15326934CRJ1401_10

Dutton, J. E., Dukerich, J.M., \& Harquail, C.V. (1994). Organizational images and member identification. Administrative Science Quarterly, 39(2), 239-263. https://doi.org/10.2307/2393235

Eikhof, D. R. \& Haunschild, A. (2006). Lifestyle meets market. Bohemian entrepreneurs in creative industries. Creativity and Innovation Management, 15(3), 234-241. https://doi.org/1467-8691.2006.00392.x.

Eikhof, D. R. \& Haunschild, A. (2007). For art's sake! Artistic and economic logics in creative production. Journal of Organizational Behavior, 28, 523-538. https://doi.org/10.1002/job.462

Elsbach, K. D. (2009). Identity affirmation through 'signature style': A study of toy car designers. Human Relations, 62(7), 1041-1072. https://doi.org/10.1177/0018726709335538

Elsbach, K. D., \& Dukerich, J. M. (2016). The undesired self. In M.G. Pratt, M. Schultz, B. E. Ashforth and D. Ravasi (Eds.), The Oxford handbook of organizational identity, (pp. 257-275). Oxford, UK: Oxford University Press.

Elsbach, K. D., \& Flynn, F. J. (2013). Creative collaboration and the self-concept: A study of toy car designers. Journal of Management Studies, 50(4), 515-544. https://doi.org/10.1111/joms.12024

Farber, S. (2009, October 10). Waking sleeping beauty - Film review. The Hollywood Reporter. https://www.hollywoodreporter.com/review/waking-sleeping-beauty-filmreview-93493

Gautam, T., Van Dick, R., \& Wagner, U. (2004). Organizational identification and organizational commitment: Distinct aspects of two related concepts. Asian Journal of Social Psychology, 7, 301-315 https://doi.org/10.1111/j.1467-839X.2004.00150.x.

Gil, R. \& Spiller, P. T. (2007). The organizational dimensions of creativity: Motion picture production. California Management Review, 50(1), 243-260. https://doi.org/10.2307/41166426 
Gotsi, M., Andriopulos, C., Lewis, M.W., \& Ingram, A. E. (2010). Managing creatives: Paradoxical approaches to identity regulation. Human Relations, 63(6), 781-805. https://doi.org/10.1177/0018726709342929

Hackley, C., \& Kover, A. J. (2007). The trouble with creatives: Negotiating creative identity in advertising agencies. International Journal of Advertising, 26(1), 63-78.

Hahn, D. (Director). (2009). Waking sleeping beauty [Motion Picture]. United States of America: Stone Circle Pictures. https://doi.org/10.1080/02650487.2007.11072996

Hardy, C. \& Phillips, N. (2004). Discourse and power. In D. Grant, C. Hardy, C. Oswick and L. Putnam (Eds), The SAGE handbook of organisational discourse. London, England: Sage, 299-316.

Hesmondhalgh, D., \& Baker, S. (2010). A very complicated version of freedom: Conditions and experiences of creative labour in three cultural industries. Poetics, 38, 4-20. https://doi.org/10.1016/j.poetic.2009.10.001.

Hogg, M. A., Abrams, D., \& Brewer, M. B. (2017). Social identity: The role of self in group processes and intergroup relations. Group Processes \& Intergroup Relations, 20(5), 570-581 https://doi.org/10.1177/1368430217690909.

Huws, U. (2007). The spark in the engine: creative workers in a global economy. Work Organisation, Labour \& Globalisation, 1(1), 1-12. https://www.jstor.org/stable/10.13169/workorgalaboglob.1.1.0001

Huws, U. (2010). Expression and expropriation: The dialectics of autonomy and control in creative labour. Ephermera: Theory \& Politics in Organization, 10(3/4), 504-521. http://www.ephemerajournal.org/

Ibrahim, A.M. (2012). Thematic analysis: a critical review of its process and evaluation. Croatia: Zagreb.

Jung, D., Yammarino, F.J. \& Lee, J.K. (2009). Moderating role of subordinates' attitudes on transformational leadership and effectiveness: A multi-cultural and multi-level perspective. The Leadership Quarterly, 20(4), 586-603. https://doi.org/10.1016/j.leaqua.2009.04.011.

Karanika-Murray, M., Duncan, N., Pontes, H. M., \& Griffiths, M. D. (2015). Organizational identification, work engagement, and job satisfaction. Journal of Managerial Psychology, 30(8), 1019-1033. https://doi.org/10.1108/JMP-11-2013-0359.

Kreiner, G. E., \& Ashforth, B. E. (2004). Evidence towards an expanded model of organizational identification. Journal of Organizational Behavior, 25(1), 127. https://doi.org/10.1002/job.234

Lee, S. M. (1971). An empirical analysis of organizational identification. Academy of Management Journal, 14, 213-226. https://doi.org/10.2307/255308

Lee, E. S., Park, T. Y., \& Koo, B. (2015). Identifying organizational identification as a basis for attitudes and behaviors: A meta-analytic review. Psychological Bulletin 141(5), 1049-1080. https://doi.org/10.1037/bul0000012.

Lunenburg, F. C. (2012). Power and leadership: An influence process. International Journal of Management Business, and Administration, 15(1), 1-9. 
Macaulay, S. (2010, March 26). Don Hahn, Peter Schneider on waking sleeping beauty. Filmmaker Magazine. https://filmmakermagazine.com/6347-don-hahn-peterschneider-of-waking-sleeping-beauty-by-scott-macaulay/\#.XK_vM5MzZPM

Mainemelis, B., Kark, R., \& Epitropaki, O. (2015). Creative leadership: A multi-context conceptualization. Academy of Management Annals, 9(1), 393-482. https://doi.org/10.1080/19416520.2015.1024502.

Marx, K. (1852/1978). The Eighteenth Brumaire of Louis Bonaparte. In R.C. Tucker (ed.), The Marx-Engels Reader, (2nd ed.), New York, NY: W.W. Norton \& Company.

Moultrie, J. \& Young, A. (2009). Exploratory study of organizational creativity in creative organizations. Creativity and Innovation Management, 18, 299-314. https://doi.org/10.1111/j.1467-8691.2009.00536.x

Parekh, B. (2009). Logic of identity. Politics, Philosophy \& Economics, 8(3), 267-284. https://doi.org/10.1111/10.1177/1470594X09105387

Peterson, R. A., \& Anand, N. (2004). The production of culture perspective. Annual Review of Sociology, 30, 331-334.

https://doi.org/10.1111/10.1146/annurev.soc.30.012703.110557

Peretti, P. O., \& O'Connor, P. (1989). Effects of incongruence between the perceived self and the ideal self on emotional stability of stripteasers. Social Behavior and Personality, 17(1), 81-92. http://dx.doi.org/10.2224/sbp.1989.17.1.81.

Pieterse, A. N., van Knippenberg, D., Schippers, M. \& Stam, D. (2010). Transformational and transactional leadership an innovative behavior: The moderating role of psychological empowerment. Journal of Organizational Behavior, 31, 609-623. https://doi.org/10.1111/10.1002/job.650.

Pirola-Merlo, A., \& Mann, L. (2004). The relationship between individual creativity and team creativity: Aggregating across people and team. Journal of Organizational Behavior, 25(2), 235-257. https://doi.org/10.1111/10.1002/job.240.

Powell, S. (2007). Organizational marketing, identity and the creative brand. Brand Management, 15(1), 41-56. https://doi.org/10.1057/palgrave.bm.2550109

Raven, B. H. (1992). A power/interaction model of interpersonal influence: French and Raven thirty years later. Journal of Social Behavior \& Personality, 7(2), 217-244.

Reid, A., Petocz, P., \& Bennett, D. (2016). Is creative work sustainable? Understanding identity, motivation, and worth. Australian Journal of Career Development, 25(1), 33-41. https://doi.org/10.1177/1038416216637089

Rogers, K. M., Corley, K. G, \& Ashforth, B. E. (2017). Seeing more than orange: Organizational respect and positive identity transformation in a prison context. Administrative Science Quarterly, 62(2), 219-269. https://doi.org/10.1177/0001839216678842

Rowlands, L., \& Handy, J. (2012). An addictive environment: New Zealand film production workers' subjective experiences of project-based labour. Human Relations, 65(5), 657-680. https://doi.org/10.1177/0018726711431494.

Scott, C.R., Corman, S.R., \& Cheney, G. (1998). Development of structurational model of identification in the organization. Communication Theory, 8(3), 298-336. https://doi.org/10.1111/j.1468-2885.1998.tb00223.x 
Sluss, D. M., \& Ashforth, B. E. (2007). Relational identity and identification: Defining ourselves through work relationships. Academy of Management Review, 32(1), 9-32. https://doi.org/10.5465/amr.2007.23463672

Stets, J. E., \& Burke, P. J. (2000). Identity theory and social identity theory. Social Psychology Quarterly, 63(3), 224-237. https://doi.org/10.2307/2695870

Stewart, J. B. (2005). Disney War. New York, NY: Simon \& Schuster.

Swann Jr, W. B., Milton, L. P., \& Polzer, J. P. (2000). Should we create a niche or fall in line? Identity negotiation and small group effectiveness. Journal of Personality and Social Psychology, 79(2), 238-250. https://doi.org/10.1037/0022-3514.79.2.238

Tajfel, H. (1982). Social psychology of intergroup relations. Annual Review of Psychology, 33, 1-39. https://doi.org/10.1146/annurev.ps.33.020182.000245.

Taylor, S. \& Littleton, K. (2012). Contemporary identities of creativity and creative work. London, UK: Routledge.

Tompkins, P. K., \& Cheney, G. (1985). Communication and unobtrusive control in contemporary organizations. In R.D. McPhee and P.K. Tompkins (Eds.), Organizational communication: Traditional themes and new directions (179-210). Beverly Hills, California: SAGE Publications.

van Knippenberg, D. \& van Kleef, G. A. (2016). Leadership and affect: Moving the hearts and minds of followers. Academy of Management Annals, 10(1), 799-84. https://doi.org/10.1080/19416520.2016.1160515.

West, M. A. (1990). The social psychology of innovation in groups. In M. A. West, \& J. L. Farr (Eds.), Innovation and creativity at work: Psychological and organizational strategies (101-122). Chichester: Wiley.

Wrzesniewski, A., Dutton, J. E. \& Debebe, D. (2003). Interpersonal sensemaking and the meaning of work. Research in Organizational Behavior, 25, 93-135. https://doi.org/10.1016/S0191-3085(03)25003-6.

Corresponding author: Angelique Nairn

Contact email: angelique.nairn@aut.ac.nz 